\title{
PENDAMPINGAN IBU NIFAS DALAM PEMBERIAN ASI EKSKLUSIF
}

Oleh :

Sri Yunita Suraida Salat ${ }^{1)}$, ArisdaCandraSatriaawati, S.ST.,M.Tr.Keb ${ }^{2)}$

${ }^{1)}{ }^{2}$ Fakultas Ilmu Kesehatan, Universitas Wiraraja

Email ; yuitafik@wiraraja.ac.id

\begin{abstract}
Abstrak
Pemerintah memiliki kebijakan nasional tentang program terkiait pemberian ASI eksklusif yang tertuang dalam Peraturan Pemerintah Republik Indonesia Nomor: 33 Tahun 2012. Cakupan bayi diberi ASI Eksklusif di Kabupaten Sumenep Tahun 2017 sebesar $82,30 \%$. Namun data ini bukanlah data murni melaikan data dimana pada saat pendataan jika ada seorang bayi yang berumur 0 bulan atau 1 bulan dan bayi usia 5 bulan masih diberi ASI saja, maka pada saat itu bayi tersebut dicatat sebagai bayi yang diberikan ASI Eksklusif. Oleh karena itu angka cakupan pemberian ASI Ekslusif lebih tinggi dibandingkan dengan pemberian ASI pada usia 6 bulan murni. Rendahnya cakupan ASI Eksklusif di Kabupaten Sumenep di sebabkan oleh banyak faktor, salah satunya karena karena masih adanya kebiasaan dimasyarakat yang kurang mendukung pemberian ASI ekslusi seperti pemberian nasi atau pisang sebelum berumur 6 bulan ataupun karena ibu bekerja di luar rumah. Tujuan dari pelaksanaan pendampingan ibu nifas dalam pemberian ASI Eksklusif ini untuk membantu ibu nifas dalam memberikan ASI saja pada bayinya saat usia 0-6 bulan. Metode pelaksanaan PKM ini yaitu dengan melakukan pendampingan langsung pada ibu nifas yang masih memberikan ASI saja pada bayinya secara door to door sehingga dapat membantu ibu dalam mengatasi kesulitan yang dialami selama ibu memberikan ASI Ekslusif. Hasil dari pendampingan yang dilakukan selama 3 bulan ini yaitu $85 \%$ dari 13 ibu nifas yang dilakukan pendampingan, masih tetap memberikan ASI saja pada bayinya tanpa makanan tambahan lainnya. Hal ini menjukkan bahwa pelaksanaan pengabdian ini berjalan cukup sukses dan efektif adalam meningkatkan capukan target pemberian ASI Eksklusif.
\end{abstract}

Kata Kunci: Pendampingan, ASI Eksklusif.

\section{Pendahuluan}

Pemerintah memiliki kebijakan nasional tentang program terkiait pemberian ASI eksklusif yang tertuang dalam Peraturan Pemerintah Republik Indonesia Nomor: 33 Tahun 2012 .Dalam Rencana Strategis (Renstra) tahun 2015- 2019 target dalam cakupan ASI eksklusif sebesar $50 \%$ pada tahun 2019 (Kemenkes RI, 2015). Berdasarkan data dari Kabupaten/Kota diketahui bahwa cakupan bayi yang mendapat ASI Eksklusif di Jawa Timur tahun 2018 sebesar $76.8 \%$. Cakupan bayi diberi ASI Eksklusif di Kabupaten 
Sumenep Tahun 2017 sebesar 82,30\%. Menurut World Health Organization (WHO) maupun Kementerian Kesehatan RI, ASI Eksklusif adalah kondisi dimana seorang bayi yang berusia 0-6 bulan dan masih diberi ASI saja pada saat didata. Artinya, pada saat pendataan jika ada seorang bayi yang berumur 0 bulan atau 1 bulan dan bayi usia 5 bulan masih diberi ASI saja, maka pada saat itu bayi tersebut dicatat sebagai bayi yang diberikan ASI Eksklusif. Oleh karena itu angka cakupan pemberian ASI Ekslusif lebih tinggi dibandingkan dengan pemberian ASI pada usia 6 bulan murni. Rendahnya cakupan pemberian ASI Eksklusif di Kabupaten Sumenep di sebabkan oleh banyak faktor, salah satunya karena karena masih adanya kebiasaan dimasyarakat yang kurang mendukung pemberian ASI ekslusi tersebut antara lain pemberian nasi atau pisang sebelum berumur 6 bulan ataupun karena ibu bekerja di luar rumah.

Tujuan dari pelaksanaan pendampingan ibu nifas dalam pemberian ASI Eksklusif ini untuk membantu ibu nifas dalam memberikan ASI saja pada bayinya saat usia 0-6 bulan. Metode pelaksanaan PKM ini yaitu dengan melakukan pendampingan langsung pada ibu nifas yang masih memberikan ASI saja pada bayinya secara door to door sehingga dapat membantu ibu dalam mengatasi kesulitan yang dialami selama ibu memberikan ASI Ekslusif .

\section{Metode Pelaksanaan}

Metode pelaksanaan yang digunakan dalam pengabdian kepada masyarakat ini, yaitu dengan melakukan penyuluhan dan pendampingan kepada ibu nifas secara langsung tentang proses menyusui ASI Eksklusif pada bayinya. Sasarannya adalah ibu nifas di desa Marengan Laok pada bulan Juni sampai bulan Agustus 2021 yaitu sebanyak 13 ibu nifas. Teknik pelaksanakan pendampingan ini dilakukan dengan cara kunjungan rumah ke setiap rumah ibu nifas yang ada di desa Marengan Laok. Sebelum melakukan pengabdian kepada masyarakat, para pengabdi telah mendapatkan izin pelaksanaan dari Dinas Kesehatan serta Puskesmas Kalinget yang ditembuskan ke Bidan Desa Marengan Laok sebagai penangung jawab wilayah terkait kesehatan desa. Adapun media informasi yang digunakan berupa leaflet yang diberikan ke pada ibu nifas 
Jurnal Abdiraja

ISSN : 2621-9379 (Online)

Volume 5, Nomor 1, Maret 2022

yang berisi tentang informasi ASI

Eksklusif dan teknik menyusui yang benar.

\section{Hasil Dan Pembahasan}

Pengabdian Kepada Masyarakat ini dilaksanakan sejak bulan Juni sampai dengan bulan Agustus 2021 di Desa Marengan Laok Kecamatan Kalianget Kabupaten Sumenep. Dalam pelaksanaannya pengabdi dibantu beberapa masiswa prodi D3 Kebidanan Fakultas Ilmu Kesehatan Universitas Wiraraja guna memberikan pengalaman secara langsung kepada mahasiswa dalam melakukan pendampingan kepada ibu nifas untuk menyukseskan program ASI Eksklusif. Setiap ibu nifas mendapatkan beberapa kali kunjungan dalam pendampingan pemberian ASI Eksklusif untuk memastikan serta menyelesaikan masalah ataupun kesulitan yang dialami ibu dalam menjalankan pemberian ASI Eksklusif.

Ada 13 ibu nifas yang dilakukan pendampingan. Adapun karakteritik dari 13 ibu nifas ini sebagai berikut :

1. Status Paritas

Grafik 1 Status Paritas Ibu nifas

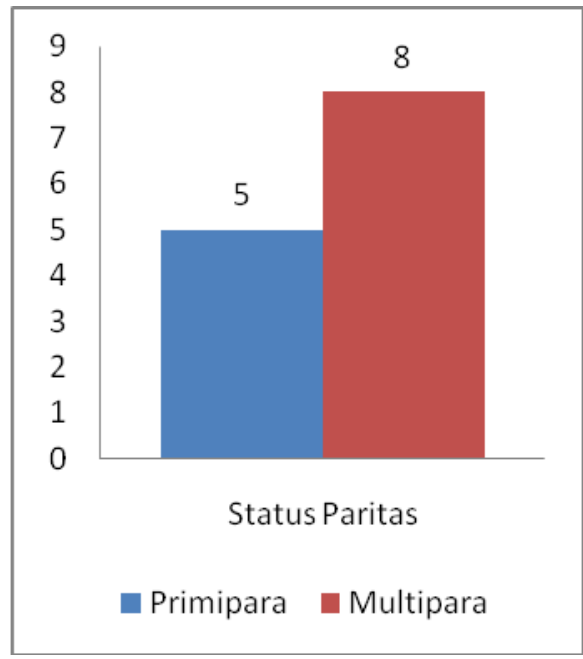

Dari 13 ibu nifas, lebih dari separuh yaitu $62 \%$ ibu dengan status multipara. Dari 8 ibu yang memiliki status paritas multipara diketahui selurunya belum pernah melakukan ASI Eksklusif pada anak sebelumnya.

2. Pendidikan Ibu nifas

Grafik 2 Pendidikan Ibu nifas

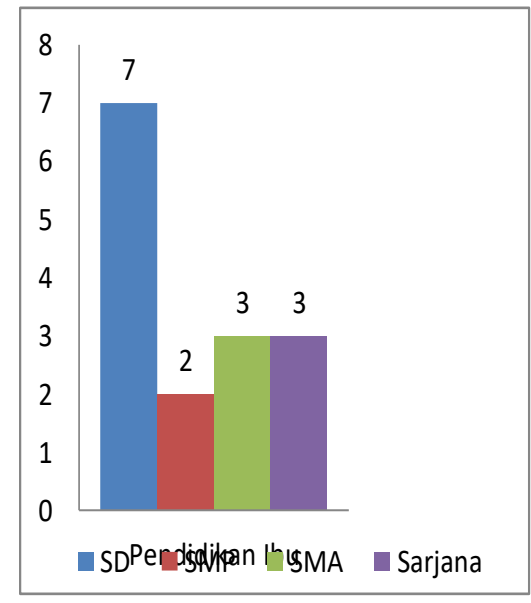

Dari 13 Ibu nifas, separuhnya yaitu $54 \%$ memiliki riwayat pendidikan di tingkat sekolah dasar.

3. Umur

Grafik 2 Umur Ibu Nifas 


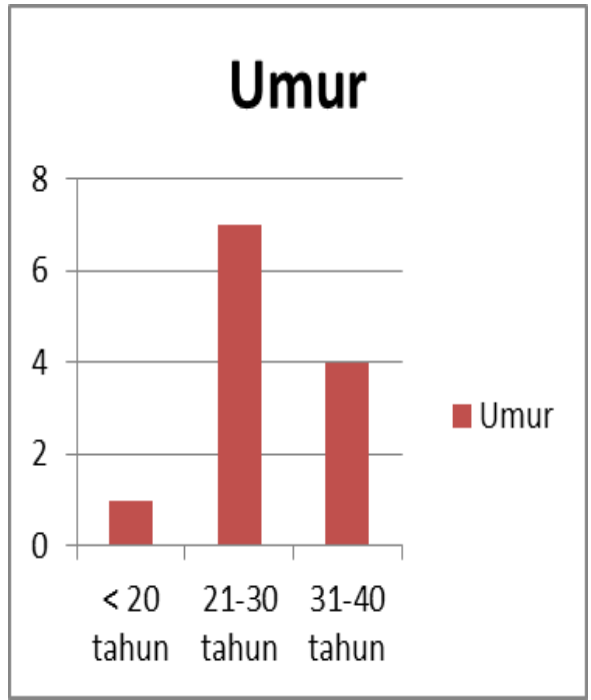

Dari 13 ibu nifas, lebih dari separuh yaitu $54 \%$ ibu dengan umur 21-30 tahun.

Dari pelaksanaan pendampingan yang dilakukan pada 13 ibu nifas di Desa Marengan Laok, ditemukan bahwa ibu nifas banyak mengalami kesulitan dalam pemberian ASI kepada bayinya. Hal ini tidak hanya terjadi pada ibu yang primipara namun juga terjadi pada ibu dengan status multipara. Adapun beberapa kesulitan yang dialami oleh ibu nifas dalam pemberian ASI Eksklusif di desa Marengan Laok yaitu kurangnya dukungan keluarga, persepsi ibu tentang ASInya yang kurang lancar, teknik menyusui ibu yang masih kurang tepat. Dari permasalahan yang ada, yang paling banyak dialami ibu nifas di Desa Marengan Laok adalah kurangnya dukungan keluarga dalam pemberian
ASI Eksklusif. Banyak keluarga dari ibu nifas yang masih mendorong ibu untuk memberikan MPASI pada bayinya pada masa nifas. Dengan adanya beberapa masalah tersebut, para pengabdi juga memberikan beberapa informasi tentang pentingnya ASI Ekslusif bagi bayi kepada keluarga ibu. Selain itu dalam proses pendampingan, pengabdi juga membantu ibu nifas dalam teknik menyusui bayi yang benar dengan beberapa posisi menyusui.

Hasil dari pendampingan ibu nifas dalam pemberian ASI Eksklusif yang dilakukan selama kurang lebih 3 bulan yaitu $84,6 \%$ ibu nifas masih tetap memberikan ASI saja kepada bayinya tanpa makanan tambahan lainnya. Sedangkan $\quad 15,4 \%$ ibu telah memberikan makanan tambahan lainnya kepada bayi dengan alasan adanya dorongan dan paksaan dari pihak keluarga ( Nenek si bayi, mertua bahkan suami) untuk memberikan susu formula ataupun pisang pada bayinya. Selain itu ibu juga merasa kewalahan dalam menyusui bayinya karena tidak ada yang membantu ibu dalam melakukan perawatan terhadap bayinya. Adapaun beberapa dokumentasi dari kegiatan ini yaitu : 


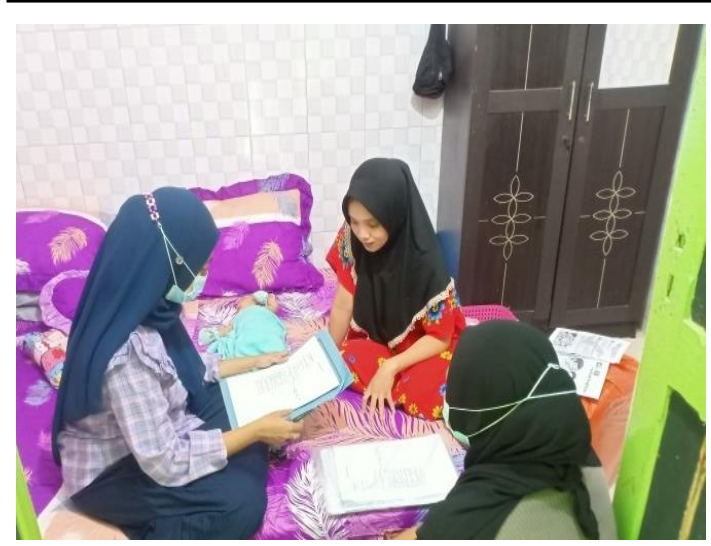

Gambar 1.

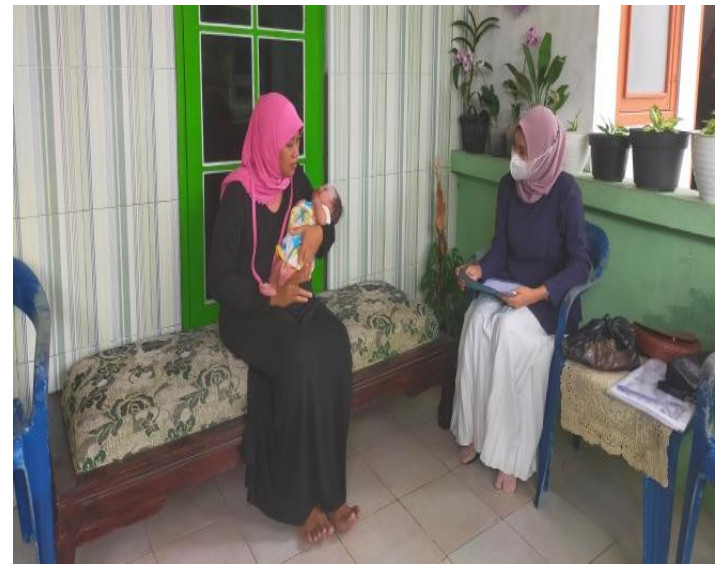

Gambar 2

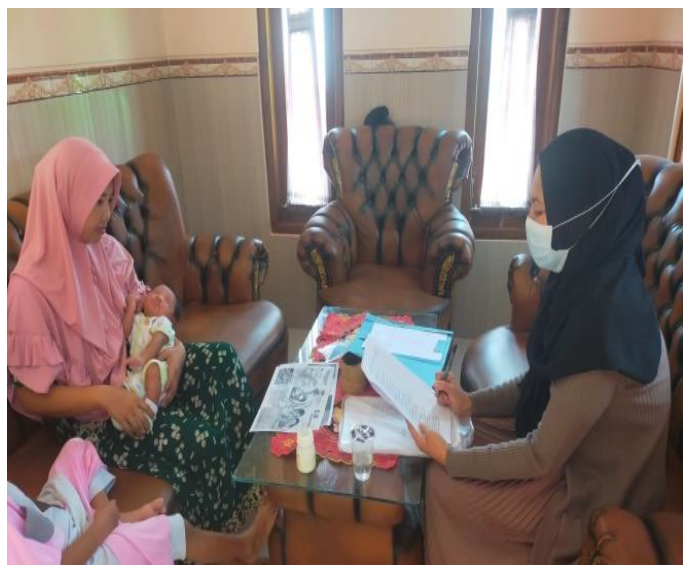

Gambar 3

\section{Kesimpulan}

Banyak faktor yang dapat mempengaruhi ibu nifas dalam keberhasilan pemberian ASI Eksklusif pada bayinya di Desa Marengan Laok, diantaranya adalah kurangnya dukungan keluarga, persepsi ibu tentang ASInya yang kurang lancar serta teknik menyusui ibu yang masih kurang tepat. sehingga dibutuhkan adanya pendampingan yang ekstra kepada ibu nifas sebagai salah satu bentuk asuhan kebidanan untuk membantu ibu dalam menyelesaikan masalah dan kesulitan yang dialaminya selama proses menyusui berlangsung. Oleh sebab itu kegiatan pengabdian kepada masyarakat ini merupakan salah satu upaya dalam mensukseskan program ASI Eksklusif pada bayi 0-6 bulan. Pelaksanaan pengabdian kepada masyarakat ini cukup berhasil dengan melihat $85 \%$ ibu yang masih memberikan ASI Ekslusif pada bayinya selama masa nifas.

\section{Ucapan Terima Kasih}

Terimakasih kepada Universitas Wiraraja yang telah memberikan bantuan Dana dalam Pelaksanaan Pengabdian Kepada Masyarakkat ini, sehingga pengabdian kepada masyarakat ini dapat terlaksana dengan lancar. Selain itu juga diucapkan terimakasih kepada mitra yaitu Bidan Desa Marengan Laok yang telah bersedia memberikan izin serta membantu dalam pelaksanaan pengabdian kepada masyarakat ini. 
Jawa Timur 2017. Nucleic Acids

\section{Daftar Pustaka}

Astuti, I. (2013). Determinan Pemberian ASI Eksklusif Pada Ibu nifas. Health Quality.

Aziza, C. (2019). Rahasia Sukses Menyusui Panduan Memberi ASI Eksklusif. Nue Mediatama : Surabaya.

Azriani, D. (2013). Keberhasilan Pemberian Asi Eksklusif. Jurnal Health Quality.

Dinas Kesehatan Propinsi JawaTimur. (2017). Profil Kesehatan Propinsi
Research.

Linda, E. (2019). ASI Eksklusif. Yayasan Jamiul Fawaid : Cilacap.

Robin Dompas, (2021). Peran Keluarga Terhadap Pemberian ASI Eksklusif. Deepublish : Sleman.

Sumenep, D. K. K. (2016). Profil Kesehatan Kabupaten Sumenep Tahun 2016 (Data 2015). In Dinas Kesehatan Kabupaten Sumen 